Maastricht Graduate School of Governance (MGSoG)

\title{
Exploring human autonomy \\ effectiveness: \\ Project logic and its effects \\ on individual autonomy
}

\author{
Mirtha R. Muñiz Castillo \\ Des Gasper
}

J une 2009

Working Paper

MGSOG/ 2009/ WP006

\section{Maastricht Graduate School of Governance (MGSoG)}




\section{Maastricht Graduate School of Governance}

The 'watch dog' role of the media, the impact of migration processes, health care access for children in developing countries, mitigation of the effects of Global Warming are typical examples of governance issues - issues to be tackled at the base; issues to be solved by creating and implementing effective policy.

The Maastricht Graduate School of Governance, Maastricht University, prepares students to pave the road for innovative policy developments in Europe and the world today.

Our master's and $\mathrm{PhD}$ programmes train you in analysing, monitoring and evaluating public policy in order to strengthen democratic governance in domestic and international organisations. The School carefully crafts its training activities to give national and international organisations, scholars and professionals the tools needed to harness the strengths of changing organisations and solve today's challenges, and more importantly, the ones of tomorrow.

\section{Authors:}

Mirtha R. Muñiz Castillo

Maastricht Graduate School of Governance

Maastricht University

Email: mirtha.munizcastillo@maastrichtuniversity.nl

Prof. Dr. Des Gasper

Institute of Social Studies, The Hague

Erasmus University Rotterdam

Email: gasper@iss.nl

\section{Mailing address}

Universiteit Maastricht

Maastricht Graduate School of Governance

P.O. Box 616

6200 MD Maastricht

The Netherlands

\section{Visiting address}

Kapoenstraat 2, $6211 \mathrm{KW}$ Maastricht

Phone: +31 433884650

Fax: +31 433884864

Email: info-gov@maastrichtuniversity.nl 


\title{
Exploring human autonomy effectiveness: \\ Project logic and its effects on individual autonomy
}

\author{
Mirtha R. Muñiz Castillo and Des Gasper
}

\begin{abstract}
We have proposed elsewhere an alternative analytical framework for project evaluation and a criterion of 'human autonomy effectiveness' to examine the effects of aid projects on the lives, opportunities and capacities of participants (Muñiz Castillo \& Gasper, 2009). A project is human-autonomy effective when it promotes an expansion of individual autonomy that allows people to support and sustain their own development, in a way that does not constrain other priority capabilities.

In this paper, we explore how four aid projects influenced the autonomy of local participants, by examining their project logic. We elicit key assumptions behind the projects' design and implementation; identify significant project practices (forms of interaction and practical strategies); and analyse the practices' possible influence on the participants' autonomy.

The paper shows that we need to understand the project logic in a deeper way than through the conventional 'logical framework' approach. Power relations between project stakeholders are crucial elements of the actual practices that influence the access to resources as result of the projects. Moreover, practices such as top-down design or excessive conditionality could harm participants' autonomy despite being supportive to other goals, and thus have negative longer-run significance. When project practices constrain the opportunities and perceived competence of individuals to help themselves, the 'development' or change promoted by those projects is not sustainable (Ellerman, 2006).
\end{abstract}

\section{Keywords:}

Autonomy, effectiveness, project logic, management practices, human development

\footnotetext{
* We thank participants from Maastricht Graduate School of Governance, especially Eddy Szirmai, for their comments in a PhD research meeting of 12 May, 2009. Our thanks also go to Kunibert Raffer, our discussant at the $7^{\text {th }}$ Development Dialogue: 'Setting the Agenda for Development', the Institute of Social Studies, The Hague (2-3 June, 2009). All comments and errors are our own responsibility.

This paper is based on a $\mathrm{PhD}$ research project by Mirtha R. Muñiz Castillo, which was financially supported by the Luxembourg Ministry of Culture, Higher Education and Research, Ministry of Foreign Affairs, and Fonds National de la Recherche (FNR).
} 


\section{Exploring human autonomy effectiveness:}

\section{Project logic and its effects on individual autonomy}

The poor, unless their condition is deliberate (like a monk), already have a history of ineffectual action to better their condition, so any kind of assistance that reinforces that perceived inability to help themselves is simply the wrong kind of assistance, no matter how well-intended (Ellerman, 2006, p. 127).

\section{Introduction}

Concerns on aid effectiveness have grown as there are now consensual priority goals to promote well-being (i.e., the millennium development goals) and more flows are allocated to poor countries year on year. At the project level, effectiveness has been usually assessed in terms of the achievement of operational outputs (operational effectiveness), intended impacts, or objectives expressible in monetary terms (economic effectiveness).

In contrast, we have proposed elsewhere an alternative analytical framework for project evaluation and a criterion of 'human autonomy effectiveness' to examine the effects of aid projects on the lives, opportunities and capacities of participants (Muñiz Castillo \& Gasper, 2009). We consider human autonomy as a person's capability to make reasoned choices in significant matters and achieve positive results in his or her life. A project is human-autonomy effective when it promotes an expansion of autonomy that allows people to support and sustain their own development, in a way that does not constrain other priority capabilities.

Individual autonomy can be studied in terms of three determinants: agency, the internal capacity to make reasoned choices and act accordingly; entitlements, here meaning individual access to inputs; and the multilevel structural contexts which support or constrain the exercise of autonomy. Projects could promote individual autonomy through supporting (i) a positive change in its determinants, and/or (ii) the achievement of personal goals, and/or (iii) the exercise of autonomy during the project cycle. In this paper, we focus on the first channel, while recognising that the other channels can indirectly influence agency.

We explore how four aid projects have influenced the determinants of individual autonomy of local participants by examining their explicit and implicit logic, i.e., what was planned in official documents, what was done and how it was done. First, we elicit key assumptions behind their design and implementation. Then, we identify significant project practices (forms of interaction and practical strategies) and, finally, we analyse their possible influence on the participants' autonomy.

The paper draws on a completed study (2004-8) of four projects in Nicaragua and El Salvador (Muñiz Castillo, 2009). Data used include project documents, public national reports, external statistics, stakeholders' interviews, focus group discussions (FGDs) and a small questionnaire survey $(\mathrm{n}=172)$. FGDs were the main way to understand the implicit logic of the four projects. They were crucial to obtain contextualised perceptions of autonomy and change and to explain possible project influences. Non-leaders and leaders were contacted separately. Leaders are people with strong influence on their neighbours, such as a community association office-holder, a school teacher or a priest.

The analysis is interpretive, aiming at understanding changes in the lives of project participants based on their own understandings. Qualitative analysis was complemented with quantitative analysis to triangulate data, produce complex data and explore alterna- 
tive hypotheses. Hypotheses raised by different FGDs and other stakeholders were progressively compared.

Section 2 describes the four projects studied. Section 3 focuses on the projects' stated purposes and implicit assumptions. Section 4 looks at the implicit theories signalled by specific practices. Section 5 explores how certain project practices could influence individual autonomy. Section 6 concludes.

\section{The case studies: communities and projects}

The projects studied were executed between 1999 and 2005 with assistance from Luxembourg's aid agency. They aimed at extending the access of households to infrastructure in water and sanitation (water projects) or housing and social services (reconstruction projects). The aid modality was bilateral grant, whose terms are agreed upon by the ministries of foreign affairs of the donor and the recipient countries. The formal counterparts were the public water companies (for the water projects) or the municipal governments (for the reconstruction projects).

In most cases, the projects were managed as follows. The aid agency set up a project implementation unit (PIU) in the field, led by a foreign project chief. It coordinated the actions of local private constructors, supervisors, and NGOs subcontracted to execute different components of the projects. For the water projects, the public water companies were supervising and executing entities at the same time.

Table 1: The four cases

\begin{tabular}{|c|c|c|c|}
\hline & \multicolumn{2}{|c|}{ Country } \\
\hline & & Nicaragua & El Salvador \\
\hline \multirow{2}{*}{ Sector } & Reconstruction & $\begin{array}{c}\text { Santa María } \\
\text { (tragedy caused by a mudslide) } \\
05 / 1999-10 / 2001 \\
\end{array}$ & $\begin{array}{c}\text { San Agustín } \\
\text { (disaster caused by earthquakes) } \\
10 / 2001-03 / 2005 \\
\end{array}$ \\
\hline & Water & $\begin{array}{c}\text { San Fernando } \\
\text { (deficit caused by Hurricane Mitch) } \\
09 / 2002-01 / 2005\end{array}$ & $\begin{array}{c}\text { Agua Fría } \\
\text { (structural deficit) } \\
10 / 2001-01 / 2004\end{array}$ \\
\hline
\end{tabular}

Note: The cases have the names of the localities, not of the projects (some projects covered several localities). Reasons for the need of aid appear between parentheses. The project execution periods in the specific localities are shown at the bottom of each cell.

Table 1 presents the cases. In the reconstruction cases, the need for aid was due to disasters. In 1998, the inhabitants of Santa María were living in two towns at the slopes of the Casitas volcano, when a mudslide fuelled by Hurricane Mitch wiped away their towns, killing many of their relatives and friends (2,513 people died). Survivors were relocated to Finca Santa María (a large farm) bought by several donors. For the inhabitants of San Agustín, the earthquake brought material destruction; they lost their houses and social infrastructure. Both cases stirred up public attention due to the magnitude of the losses and the acute poverty of the residents. San Agustín is one of the poorest municipalities of El Salvador, classified as marked by severe extreme poverty, the worst situation in a four-type classification (FLACSO, 2005).

In the water cases, the infrastructure deficits were of a different nature. In San Fernando, Hurricane Mitch badly damaged the existing drinking water system. In Agua Fría, a drinking water system had not been available and the earthquakes caused only minor damage to some houses. 


\subsection{The four communities before the projects}

The four localities are relatively small, each with between 350 and 500 households. However, San Agustín and San Fernando are municipal centres (headquarters of the municipal government and the mayor) so that they are better connected with other villages than are Agua Fría and Santa María, which are a canton and a colony, respectively. Cantons, usually rural, are smaller parts of municipalities, and a colony is even smaller than a canton.

To understand how people perceive the projects and their effects on their lives, it is necessary to highlight some special features of the communities. In this study, community refers to individuals who live in the same territory or, even having emigrated, keep strong family ties in their locality. ${ }^{1}$

In Santa María, the survivors of the Casitas disaster came from two different towns. There was no sense of shared community. People were too hurt by the mudslide and still grieving, without adequate psychological support; there was much uncertainty and material lacks. New self-nominated leaders emerged and, grouped into a survivors' association, led all reconstruction efforts. They even attempted to invade private lands to establish a new town, as many residents had done in 1979 during the agrarian reform.

In San Agustín, there was an active, broad-based municipal committee, integrated by former guerrilla fighters, former soldiers, and cooperative leaders. This committee brought together local committees and had the support of an experienced NGO. It was coordinating all reconstruction projects in the municipality. The massive emigration caused by the civil war (1980-1992), which had reduced the population by more than two-thirds over two decades, had reversed since new projects started.

Comparing these two cases, the disasters had different meanings. In Santa María, the disaster was a 'tragedy'. In San Agustín, it was an 'opportunity' because foreign aid arrived promptly and leaders felt ready to take the necessary measures.

In San Fernando, residents had had access to safe drinking water in the past and were dissatisfied with the public water company. There was no formal community organisation. Moreover, many people had supported the contra guerrillas during the 1980s and, since then, strong political divisions had emerged. People felt they were considered different and wealthier, for which they were abandoned by the state. The water project had a symbolic value for them: it was the first aid project that would benefit everyone.

In Agua Fría, there was a development association and neighbourhood committees. Formal leaders were managing two gravity (untreated) water systems that covered a small part of the population. Moreover, they had searched for potable water alternatives with the municipality government and the public water company. However, the social context was affected by competition for the scarce water resource and growing insecurity from the presence of youth gangs.

Comparing these two cases, the main difference is the existence of formal community leaders in Agua Fría with management experience and remittance support, in contrast to the lack of interest of San Fernando residents in public affairs.

\footnotetext{
${ }^{1}$ A community is not a homogenous group. Its members may share some values and have others in conflict. Within a poor community, individuals have different entitlements, life experiences and interests. They may interact in different formal or informal networks and, for this reason, have different perceptions of their community. However, shared history and social experiences influence the reality of individuals and their potential for autonomy expansions in each case. They influence the internal contexts of agency (i.e., personality and cultural context). See Muñiz Castillo, 2009.
} 
With respect to relative affluence before the disasters, San Agustín was the poorest locality. People suffered long-term poverty associated with years of exclusion during and after the civil war. Agua Fría was the less poor locality given that most households relied on remittances. The inhabitants of San Fernando had relatively better living standards than those of Santa María, living at the slopes of Casitas volcano. However, the latter enjoyed a life without acute lacks, based on self-consumption farming and NGO help. The mudslide of Casitas caused by Hurricane Mitch changed everything.

Figure 1 compares the situation of the households in the four localities after the disasters. Living standards differ across cases. In Agua Fría, households living in extreme poverty reach $17 \%$ of the total. In contrast, about $72 \%$ of households in Santa María live in extreme poverty ${ }^{2}$, as direct consequence of the 1998 tragedy. Having lost their lands, Santa María residents do any kind of work to survive. The lives of the households in the water cases (generally more affluent) were less affected by disasters.

Figure 1: Cases compared by relative affluence and disaster impact

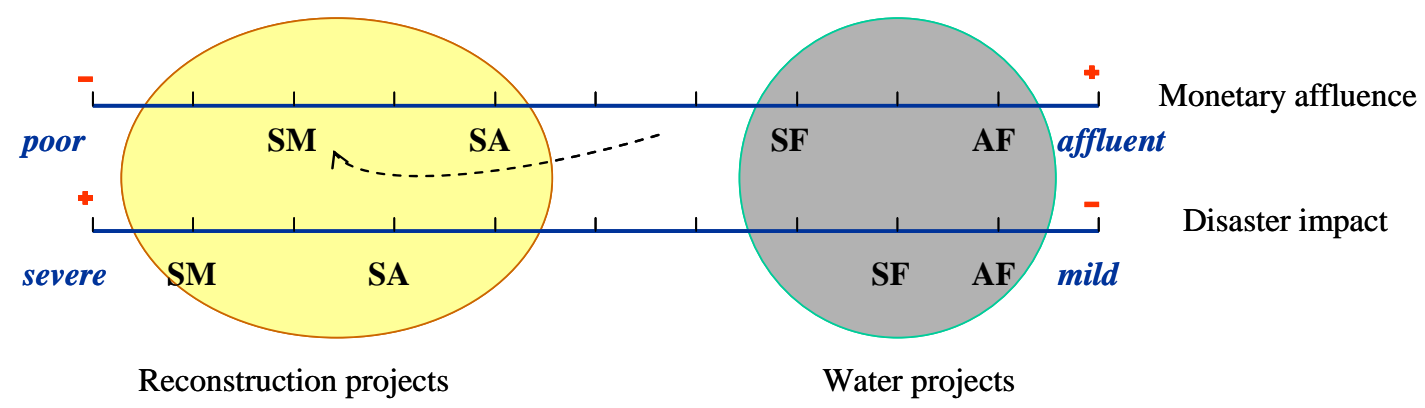

Legend: SM = Santa María, SA = San Agustín, SF = San Fernando, and AF = Agua Fría .

Note: The arrow signals the fall in living standards of SM residents.

In all four cases, before and after the projects, most households depend on agriculture activities despite the urban layout of some villages and the existence of seasonal migration. More than half of the survey respondents regarded themselves as farmers. Households plan their activities in relation to agriculture. In order to support this activity, they invest resources such as communal solidarity work, children's work and remittances savings. They partially overcome shortage periods related to the agriculture seasonality through migration, housemaid work or petty trade activities.

\subsection{An overview of the projects}

Despite the uniqueness of each in regard to location, institutional context or community dynamics, the cases have important similarities. First, the projects included a component of self-construction with two modalities. In the reconstruction projects, one member of each household worked in small teams (between five and six people) during two or three months as an assistant bricklayer to construct his or her house. In the water projects, each household built its home sanitation system to dispose of grey waters, assembled their latrines with the guidance of bricklayers, and performed other works. Participants attended training sessions in groups (between 25 and 40 people) and worked in teams for other activities.

Second, community organisations participated during the implementation of the four projects, although to different degrees. In most cases, they worked together with social promoters to mobilise their neighbours and supervise activities. The municipal commit-

\footnotetext{
${ }^{2}$ These rates are based on the questionnaire survey administered during the fieldwork, using official poverty lines.
} 
tee in San Agustín and the nascent communal committee in San Fernando were the most and least involved in the projects (see section 3.2).

These features indicate that formulators considered that local participation was valuable, although the kind of participation was not explicit in all cases. It depended on several factors related to intra-community relations, the local leaders' management experience, and the relations between project staff and stakeholders (see sections 3.2 and 3.3).

\section{- The reconstruction projects}

Both reconstruction projects were complex (see Table 2). The main difference concerns project management. In Santa María, a NGO was hired to manage this project and two other projects funded by different donors. In San Agustín, a working group, formed by the project chief, two municipal committee members, and one representative of each partner NGO, was the main decision maker (see section 4.3).

Table 2: Goals and results of the reconstruction projects

\begin{tabular}{|c|c|}
\hline $\begin{array}{l}\text { Santa María } \\
(05 / 99-10 / 01)\end{array}$ & $\begin{array}{l}\text { - Goal: Economic and social rehabilitation of households. } \\
\text { - Components: Housing construction, water and agriculture (three different donors). } \\
\text { - Main results: } \\
\checkmark \text { Tangible outputs were achieved. } \\
\quad \times \text { Agricultural project was not sustainable. } \\
\quad \text { × Residents do not have the property titles of their houses. }\end{array}$ \\
\hline $\begin{array}{l}\text { San Agustín } \\
(10 / 01-03 / 05)\end{array}$ & $\begin{array}{l}\text { - Goal: Reduction of the vulnerability of the municipality. } \\
\text { - Components: Housing, legalisation of property and participatory municipal planning. } \\
\text { - Main results: } \\
\checkmark \text { Supported an ongoing process of social change. } \\
\checkmark \text { Good quality houses and social infrastructure. } \\
\quad \times \text { No effect on reducing the financial vulnerability of the local government. }\end{array}$ \\
\hline
\end{tabular}

Extracted from Muñiz Castillo (2009, Table 10-2)

In terms of tangible outputs, both projects (individually or with others) provided houses, schools, water service, and social infrastructure. Hence, they supported crucial needs related to physical security, health, relatedness and recreation, among others.

The projects addressed differently two aspects important to participants: legal ownership of the houses, and productive initiatives that could support their livelihoods.

First, in Santa María, the municipality government could not register the property titles, so residents do not feel secure. In contrast, the project in San Agustín financed all the legal procedures, registering not only new property titles but also existing informally owned lands and undocumented citizens. ${ }^{3}$

Second, only in Santa María was there an agricultural project which, however, did not succeed (see section 3.1). In San Agustín, the project did not support any productive project, although residents had identified several possible projects in the municipal plan. In fact, the projects had different emphases. The Santa María project centred on individuals and they needed an economic activity to mend their lives. San Agustín centred on local institutions. It aimed to support the management skills of leaders and municipality staff so that these local actors could open up opportunities to residents (e.g., by preparing funding project proposals).

\footnotetext{
${ }^{3}$ Some families had inherited lands from generations of colonos (former plantation workers) and had never registered their properties. Others simply could not afford the registration costs. Moreover, a fire in the municipality hall, during the civil war, destroyed many documents.
} 


\section{- $\quad$ The water projects}

The water projects were managed by a project implementation unit (PIU) and were proposed and co-executed by the public water companies. An ongoing problem for both projects was the uncertainty about the authority, powers and duties of municipality governments and about reforms in the water sector. Moreover, the Agua Fría project was affected by governance problems within the water company, which faced accusations of corruption, internal restructuring, and high staff rotation (LD, 2004; Herrera, 2003).

Table 3 summarises the water projects. Both projects provided domiciliary water connections, required home sanitation systems from households ${ }^{4}$, and organised training sessions to build small infrastructure or promote change in hygiene habits. In addition, the Agua Fría project financed latrines (here San Fernando had a lower, but some, coverage) and ecological wood stoves for households, promoted diverse reforestation and soil protection activities, and supported the construction of a reservoir.

Table 3: Goals and results of the water projects

\begin{tabular}{|c|c|}
\hline $\begin{array}{l}\text { San Fernando } \\
(09 / 02-01 / 05)\end{array}$ & $\begin{array}{l}\text { - Goal: Improvement of health and living conditions of residents. } \\
\text { - Components: Water, sanitation; technical cooperation. } \\
\text { - Main results: } \\
\checkmark \text { A permanent service and good quality water. } \\
\checkmark \text { Some women can participate in the municipal development committee. } \\
\quad \text { × High water tariffs put at risk the entitlement to safe drinking water. }\end{array}$ \\
\hline \begin{tabular}{|l|} 
Agua Fría \\
$(10 / 01-01 / 04)$
\end{tabular} & $\begin{array}{l}\text { - Goal: Improvement of health and living conditions of residents. } \\
\text { - Components: Water, sanitation, natural resources protection, fish agriculture. } \\
\text { - Main results: } \\
\checkmark \text { Access to good quality water. } \\
\quad \text { Low operational effectiveness (unreliable water service). } \\
\quad \text { × The intended micro-regional NGO was not legally constituted. }\end{array}$ \\
\hline
\end{tabular}

Extracted from Muñiz Castillo (2009, Table 10-2)

Both projects put in operation the water systems. The service is less reliable in Agua Fría due to problems within the water company and management challenges raised by a project design that covered too many activities (see section 4.1).

\section{Looking into the projects' stated purposes and implicit assumptions}

A logical framework states that certain effects will result if the intended outputs are produced. However, some important pre-conditions are not always considered and/or not always justified. This section elaborates on three key assumptions that were made in the cases studied.

\subsection{Project Assumption: 'It is possible to create an agricultural community model' 5}

'We were sent to those lands to sow rice and to plant stumps.... Whoever worked had the right to receive food.' (A man in Santa María)

In Santa María, the land assigned to survivors of the mudslide was divided in two areas, one for houses and social infrastructure (25 ha.) and the other for agriculture activities (41 ha.). The second area was a joint tenancy. Households had to construct the houses and plant in this communal land. The agricultural project started several months before

\footnotetext{
${ }^{4}$ In both countries, it is a norm that rural households connected to water systems have a home sanitation system so that grey waters infiltrate to the soil and do not contaminate the environment.

${ }^{5}$ The phrase comes from one of the donors who financed the purchase of Finca Santa María, where survivors were relocated after the mudslide (Trolese, 1999, ๆ 6).
} 
the housing project and had positive short-term results. Residents planted vegetables and fruits. They were trained and received inputs and equipment.

The decision to implement this project as a communal landholding was made by donors during the formulation. From field interviews, it seems that donors or formulators wanted to (i) secure food for landless survivors who had to start planting as soon as possible, or (ii) promote union between people who needed to work together to advance. In addition, communal farming was considered feasible given the high levels of organisation shown by survivors during the emergency period. But, there was one implicit assumption: residents could develop a sense of community and work together.

In reality, they did not trust each other. Each household would have preferred bigger individual lots to cultivate and to raise farm animals. One man expressed this:

'We have a roof but we do not have a space to work, to sow. The houses need to be enlarged [because] the family grows.... There is no space to go around the house so that children can play. We only can cultivate little things.'

People were disenchanted with a cooperative model, after the failed experience of the Sandinista cooperatives. However, the project secured participation in the agricultural project by providing extrinsic motivation: people would receive food if they worked.

Table 4 (to be read from left to right) shows a partial assessment matrix that looks at expected and actual changes in the determinants of autonomy and their possible causes (Muñiz Castillo \& Gasper, 2009). In this case, the matrix focuses on the entitlements (just one of the determinants) of project participants through the agricultural project.

Table 4: (Partial) assessment matrix for the agricultural project in Santa María

\begin{tabular}{|c|c|c|c|c|}
\hline \multirow[b]{2}{*}{$\begin{array}{l}\text { (i) Determinants } \\
\text { of autonomy }\end{array}$} & \multicolumn{2}{|c|}{ PROJECT LOGIC } & \multicolumn{2}{|c|}{ ACTUAL EFFECTS } \\
\hline & $\begin{array}{l}\text { (ii) Hypotheses on } \\
\text { effects }\end{array}$ & $\begin{array}{l}\text { (iii) Expected condi- } \\
\text { tions }\end{array}$ & (iv) Actual situation & $\begin{array}{l}\text { (v) Assessment of } \\
\text { effects }\end{array}$ \\
\hline \multirow{2}{*}{$\begin{array}{l}\text { Entitlements } \\
\text { To natural and } \\
\text { material re- } \\
\text { sources }\end{array}$} & $\begin{array}{l}\text { Households restart } \\
\text { their economic ac- } \\
\text { tivities. }\end{array}$ & $\begin{array}{l}\text { Communal produc- } \\
\text { tive projects secure } \\
\text { subsistence. }\end{array}$ & \multirow{2}{*}{$\begin{array}{l}\text {-The agricultural } \\
\text { project failed due to } \\
\text { climatic shocks and } \\
\text { bad management. } \\
\text {-People prefer to } \\
\text { work individually } \\
\text { and devise their own } \\
\text { survival strategies. }\end{array}$} & \multirow{2}{*}{$\begin{array}{l}\text {-No common use of } \\
\text { resources. } \\
\text {-Lowered felt com- } \\
\text { petence ('we failed'). }\end{array}$} \\
\hline & \begin{tabular}{|l} 
Assumptions: \\
-The management o \\
rotating loan systen \\
-Cultural change: $f$ \\
erative model. \\
-Weather condition
\end{tabular} & $\begin{array}{l}\text { the common land and } \\
\text { is effective. } \\
\text { nilies value a coop- } \\
\text { are favourable. }\end{array}$ & & \\
\hline
\end{tabular}

The project's logical framework did not include any explicit assumptions on these factors and links. For a description of the elements of the matrix, see Muñiz Castillo \& Gasper (2009, Table 2).

The implicit assumptions did not hold. A severe drought (2001/2002) and management problems troubled the project. The revolving fund only lasted one year and many people suspected bad handling of common resources by leaders. They were not willing to work together again because ' $\mathrm{t}$ ]here, everything gets lost' (a woman). Residents parcelled out the communal land. Only a few people work in groups, supported by a local church. Many people feel less competent because they failed. 'Those green fields should be watered, [but] no one does anything', remarked one man. Not taking into account the participants' values, socio-historical experiences and intra-community relations made the agricultural project unsustainable. 


\subsection{Project Assumption: A formal community organisation assures the sustainabil- ity of project effects}

'To assure the durability of the project effects, the partners [NGOs] will take charge of organising and advising local committees.... The participation of local population... will be promoted and considered a guarantee for the durability of the actions.' (LD, 2001a, p. 33)

It was expected that the participation of community organisations in project activities would improve the sustainability of positive outcomes. We analyse which kind of participation they had. First, the role of each community organisation was different (see Table 5).

Table 5: Participation of community organisations by locality (at different project stages)

\begin{tabular}{|l|c|c|c|c|}
\hline \multirow{2}{*}{ Project stage } & \multicolumn{2}{|c|}{ Reconstruction projects } & \multicolumn{2}{c|}{ Water projects } \\
\cline { 2 - 5 } & Santa María & San Agustín & San Fernando & Agua Fría \\
\hline Formulation & 2 & 3 & 0 & 1 \\
Implementation & 3 & 3 & 2 & 2 \\
Evaluation & 0 & 1 & 1 & 1 \\
\hline
\end{tabular}

Ratings: $0=$ leaders were not informed, $1=$ leaders were informed or consulted, $2=$ the extent of decisionmaking was low, and 3=the extent of decision-making was high.

Source: Individual interviews, FGDs and project documents (using iterative cross-checking)

At the formulation stage, only in San Agustín did community leaders make decisions through a participatory formulation (section 4.1). The self-nominated leaders of Santa María had an active role during the emergency, but after many discussions and a 'parade' of donors, decisions on project design were top-down (e.g., on village layout). The leaders in Agua Fría were only consulted over taking up the project as designed, but this decision was very significant to them.

At the implementation stage, in the water projects the community leaders carried out functions similar to those of social promoters. In this way, project staff became more familiar to aid recipients, and also transferred some costs to the leaders (cf., Cooke \& Kothari, 2004). In San Fernando, leaders felt 'happy, but very sweaty because [they] had to count, to have a list of all the materials...' (a woman leader). The leaders in the reconstruction projects were more involved. However, while in San Agustín their role was positive and constant, it became disruptive in Santa María due to political interests (Ausín Cantero, 2001a; 2001b).

At the evaluation stage, the leaders in the water projects were only informed about project results even though they wanted to discuss and solve issues such as the explosion of pipes (in Agua Fría) and the high water tariffs (in San Fernando). There were no evaluation workshops in the reconstruction projects, but leaders in San Agustín were informed through the project chief.

Second, the community organisations differed with respect to its length of existence, management experience, political and financial support, and social support from residents. However, across cases, there was no link between the past organisational experience and the degree of involvement granted to community leaders in the projects.

The type of community organisation is related to the type of locality (see Figure 2). San Agustín had one municipal committee and development association per canton, represented in such a committee. Agua Fría had one development association (because the project covered one canton) and neighbourhood committees. In Santa María, the survivors' association was the main local actor. In San Fernando, neighbourhood committees were formed during the project and grouped into a communal committee. 
Figure 2: Type of community organisation during the projects

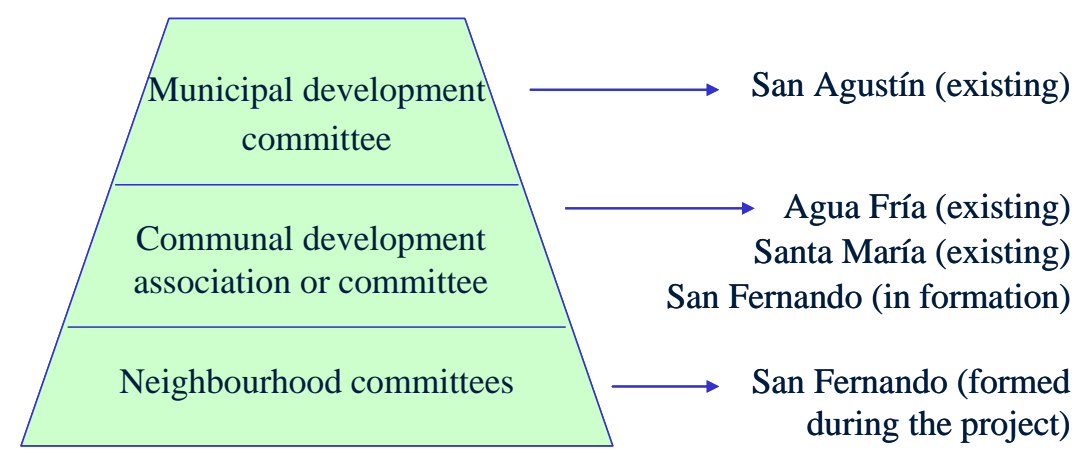

The development association in Agua Fría had more experience than the organisations in San Agustín or Santa María, but it was only given a role supportive to achievement of pre-defined project goals. This situation occurred even though: (i) the social context in Agua Fría was more favourable than in San Agustín, where residents were harmed by the civil war, or in Santa María, where the social capital had vanished with the tragedy, and (ii) the households' economic situation in Agua Fría was much better due to family remittances.

A possible explanation is the composition and commitment of project staff and the spaces open for community involvement. In San Agustín, a committed project chief led the activities with the working group. In Santa María, there was no project chief. The NGO that was responsible for managing three parallel projects needed the support of the association because it was understaffed. In both cases, the community organisations were the (informal) local counterparts of the projects given that the magnitude of the disasters exceeded the capacities and resources of the municipality governments, especially in Santa María (CENIDH, 1998; Envío team, 1998). In Agua Fría, the project chief had low visibility in comparison to the water company. When the latter faced governance problems (section 2.2), project staff focused on finishing the project rather than truly strengthening local organisations.

Third, community organisations supported the projects' operational effectiveness but not necessarily the participants' autonomy, which is required for sustained positive impact (Ellerman, 2006). The logframes of the water projects linked 'the strengthening of community organisations' to the expected project output: 'the population is sensitised to the "water, health and environment” issue'. The project logic was as follows:

Community organisation $\Rightarrow$ Operational effectiveness $\Rightarrow$ Sustainability of outputs

Leaders were to help to achieve the project outputs and to secure their sustainability; but in reality leaders had low involvement in project decisions. How could this logic work?

\section{- Complex local governance prevented the creation of a NGO in Agua Fría}

'We were three communities as if we were just one. Three communities united are powerful like the little ants that work together.' (A woman in Agua Fría)

In the Agua Fría water case, in order to assure the sustainability of outputs, project staff focused on setting up a 'stronger' community organisation. Two elements not originally planned were introduced. First, project staff supported the creation of a NGO formed by leaders from the development association and two neighbourhood committees, who were working like 'little ants'. Second, the reservoir intended to water livestock during the dry season was adapted to host a small fish farming project proposed by local leaders, with the aim of generating the resources to cover the NGO's operating expenses. 
None of the conditions required for reaching the expected outcomes occurred (Table 6).

Table 6: Assessment matrix for the community organisation in Agua Fría

\begin{tabular}{|c|c|c|c|c|}
\hline & \multicolumn{2}{|c|}{ PROJECT LOGIC } & \multicolumn{2}{|c|}{ ACTUAL EFFECTS } \\
\hline $\begin{array}{l}\text { (i) Determinants } \\
\text { of autonomy }\end{array}$ & \begin{tabular}{|l} 
(ii) Hypotheses on \\
effects
\end{tabular} & $\begin{array}{l}\text { (iii) Expected condi- } \\
\text { tions }\end{array}$ & (iv) Actual situation & $\begin{array}{l}\text { (v) Assessment of } \\
\text { effect }\end{array}$ \\
\hline \multirow[t]{2}{*}{$\begin{array}{l}\text { Local context: } \\
\text { Community } \\
\text { organisation }\end{array}$} & $\begin{array}{l}\text { Strengthening of } \\
\text { community organisa- } \\
\text { tion to carry out } \\
\text { future projects. }\end{array}$ & $\begin{array}{l}\text {-Three associations } \\
\text { grouped into a NGO } \\
\text { work for the progress } \\
\text { of the canton. } \\
\text {-The fish agriculture } \\
\text { project secures re- } \\
\text { sources for the NGO. }\end{array}$ & \multirow{2}{*}{$\begin{array}{l}\text {-There are some } \\
\text { divisions between } \\
\text { villages. } \\
\text {-The conflict with } \\
\text { the mayor has en- } \\
\text { dured. } \\
\text {-The planned micro- } \\
\text { regional NGO was } \\
\text { not formalised. } \\
\text {-Leaders rely on } \\
\text { their own resources. }\end{array}$} & \multirow[t]{2}{*}{$\begin{array}{l}\text {-No significant ef- } \\
\text { fect. } \\
\text {-Leaders had an } \\
\text { instrumental role to } \\
\text { support project ac- } \\
\text { tivities and outputs. }\end{array}$} \\
\hline & \multicolumn{2}{|c|}{$\begin{array}{l}\text { Assumptions: } \\
\text {-Intra-community relations are not hurt by } \\
\text { political interests. } \\
\text {-The relation between community leaders } \\
\text { and political leaders is fair. } \\
\text {-Weather conditions are favourable. } \\
\text {-Security conditions do not get worse. }\end{array}$} & & \\
\hline
\end{tabular}

The project's logical framework did not include any explicit assumptions on these links and conditions.

First, the mayor did not support the constitution of the NGO, which was therefore never legally registered. ${ }^{6}$ The adverse national context (section 2.2), and an impasse between project formulators and the mayor, had led to the voluntary separation of the latter from project activities. A woman reflected:

'The mayor did not help us.... When he realised that [he could not] manage the project, he did not attend the meetings anymore. They [leaders] did all the arrangements, but we lacked his signature to form the community association, which is very important for the community. He said he did not know us.'

Project staff was unable to promote consensus between the main stakeholders. Unintentionally, the project reduced the options of residents to sustain their own development.

Second, the fish agriculture project failed because the reservoir overflowed due to heavy rains, some people stole the adult fish or '[fish] were eaten by some people of the community' (a woman). Moreover, residents lacked the funds to pay a private guard and set up a security hut, necessary because the area was insecure. This failure harmed everyone, but especially leaders because they invested the most in terms of time, physical effort, and money.

The Agua Fría project could not formalise a stronger community organisation. Moreover, leaders could not assure the sustainability of the outcomes in health and sanitation. They were confused about the use of the home sanitation systems because of their lack of interest since the start. If they had made decisions and understood their importance, they could have sustained positive impacts, for instance, adapting the systems' design to the soil quality.

Next, we look at the San Agustín case, which illustrates the positive role that a project can have on local structural contexts.

\footnotetext{
${ }^{6}$ Project staff and community leaders wanted to form a micro-regional NGO based on three community development associations (ADESCOs). There was only one ADESCO before the project. To have legal standing, the two new associations had to be legally recognised by the local government. They were not.
} 
- The municipal committee in San Agustín was effectively supported by the project

'A strengthening of self-worth, awareness of the latent potentialities of the community and confidence in their own capacities by the actors [that would allow them, with the adequate training,] to propose, manage and implement future interventions and projects by themselves' (LD, 2001c, I 101)

The above statement reflects an intended project effect. This project supported a community already living a change process; residents were gradually re-valuing the need for organisation. The project aimed at improving 'the labour, organisation and management capacities of the actors and beneficiaries’ (ibid, I 213). Its logical framework included concrete assumptions on a good disposition of community organisations, political leaders and non-leaders to participate, and on local authorities' willingness to let the associations negotiate and manage projects freely.

However, most importantly, the project chief motivated community and political leaders to work together and so worked for the fulfilment of those assumptions. He supported leaders in building relations with formal institutions and in making joint decisions in the working group. He maintained close links with the NGO, known by leaders since 1999. This NGO developed a function of 'social intermediation' (Bennett et. al., 1996, cited in Thorp et al., 2005, p. 912). It supported the continuous development of leaders' skills (e.g., by courses on organisation and law), guided and monitored the process of the municipal development plan, facilitated the links between leaders and the local government, joined the working group of the project at times and participated in the general assembly of the municipal committee as a nonvoting member. Overall, the project chief was a catalyst. A woman leader reported: 'he put his intelligence and his heart'.

\subsection{Project Assumption: The manual work of beneficiaries favours their ownership of the projects}

'Here, no one can say "this house was given to me like that", rather, it cost quite some sacrifice to everyone.' (A woman in San Agustín)

'They planned the reforestation project. In winter, they sowed trees and watered them. But, in summer, how were they going to water? They did not obtain any benefit but spent money.' (A man in Agua Fría)

The participation of beneficiaries in project activities was expected to support project outputs because beneficiaries would put the interest that only an owner not a third-party has to carry out and monitor on-site activities. Moreover, manual work was seen as a local contribution to the project budgets and a signal of commitment. Below, we develop four arguments against this assumption, as too simple and unconditional.

First, felt ownership was related to the importance of the need addressed by the project. Residents accepted to work to get a house or a water connection because they valued physical security and health. They wanted 'to make [their] houses beautiful' (a man in Santa María) because they would live there and they worked very hard because 'otherwise, [they] could not afford a house like that one' (a woman).

Participants in the water projects valued having (in Agua Fría) or regaining (in San Fernando) access to safe drinking water, but they have not valued other project outputs as much, such as home sanitation systems or reforestation activities. For instance, the man in Agua Fría (cited above) perceives that the lack of sustainability of the reforestation activities was a loss for outsiders ('they'), not for him or his neighbours. 
Second, participation has a broader meaning than manual work. Muñiz Castillo (2009) used an 'involvement index' to explore the kind of participation of (non-leader) beneficiaries, based on questions related to information, opinions, skill awareness, opportunities and decisions during the project. The levels of involvement were relatively low in all cases (mean value $=1.2$, in a $0-3$ scale). ${ }^{7}$ However, survey respondents qualified participation as 'fair' (in an ordinal scale: low, fair and high). It seems that they understood participation in terms of workload or to what extent they worked in project activities as committed. Not surprisingly, the survey respondents in the reconstruction projects felt they had participated more than those in the water projects: $41 \%$ versus $27 \%$ of respondents, respectively, regarded their participation as high. However, reconstruction project participants did not feel more involved than water project participants. Manual work was not translated into high felt involvement and commitment.

On the contrary, high project workload restricted the options of many people to participate in other important activities related to their community development and, most crucially for the poorest, to secure their own subsistence (cf., Osti, 2004). A man in San Agustín recalls: 'Here, one felt that one was not going to earn for oneself... One worked here and down there [in the plot]... I felt that it was a lot [of work].' Hence, when beneficiaries in San Agustín were called for voluntary work to construct the common social buildings, they were too tired to attend. Was this a signal of lack of ownership or commitment to their community? This leads us to the next point.

Third, when subsistence is threatened, people may give up the means (satisfiers) to fulfil other needs (e.g., physical security or health) if they cannot afford to hold those means. Then, giving up resources provided by a project does not necessarily reflect a lack of ownership. For instance, in Santa María, people worked hard and valued their houses, but many had to search for jobs outside the colony given that they had lost their lands after the mudslide and could not make a living from agriculture anymore. Toward the project completion, a commission decided that only those who were living in their houses would keep them. ${ }^{8}$ This practice forced many to return, put at risk their survival and harmed their autonomy, already constrained by deprivation. Four years later, about one-third of the houses were uninhabited; people had (re-) migrated to sustain their families. Survival was a more pressing need than physical security. As Cernea (1997) points out, for farmers the 'loss of land generally has far more severe consequences than the loss of a house’ (p. 1573).

Four, ownership is rooted in personal conviction, influenced by external events. People with autonomy causality orientation (Deci \& Ryan, 1985; 2000) want more than only working hard, they want to be involved in decisions that affect their lives. This interest is a signal of ownership, which is not created but only supported or not by projects (de Valk, Apthorpe \& Guimarães, 2005; Ellerman, 2006). However, ownership could be harmed if project contexts are strongly controlling, that is, if managements exert much pressure or induce behaviour toward specific outcomes. For instance, many home sanitation systems in both water projects have not worked well. Some participants stated that they knew these systems would not work, but they did not have option to make de-

\footnotetext{
${ }^{7}$ The questions about involvement were asked to 231 respondents at a first stage of the fieldwork activities to recruit focus group participants, which were split in groups of high- and low-involvement. The index was the mean of the ratings assigned to five questions. The values for the four projects statistically behaved in similar ways (Kruskal-Wallis one-way analysis of variance by ranks).

${ }^{8}$ The project design indicated that participants had to keep their houses at least two years before getting their deeds (to be financed by other donor). For those who did not live in their assigned houses, the commission offered a monetary compensation, which was considered low by participants.
} 
sign changes that would suit their reality. Besides, 'when a project is already defined, it has to be done' (a NGO coordinator in Agua Fría). When people do not use and maintain the systems well, they tend to blame the quality of the infrastructure and not themselves (see section 4.2).

\section{Identifying implicit theories signalled by project practices}

Project practices reveal the theories, the implicit logic, assumed by the projects. In this section, we illustrate four kinds of practices with examples from the cases studied.

\subsection{Selection and design practices}

'We believe that constructing with mutual help improves the organisation and the relations among neighbours.' (A community leader in San Agustín)

'The participation of the residents was limited in quantity and quality. The diagnosis was induced toward the activities of the project, [and it was] perceived like a promotion of its activities. In other words, the residents did not have options on what to discuss.' (CODECA, 2003a, p. 22)

The participation of local stakeholders in the design of a project could vary from merely being informed to jointly defining the main aspects of the project (cf., Arnstein, 1969). Moreover, similar expressions of participation can have different effects on project outcomes and participants' autonomy in different contexts. ${ }^{9}$ In this section, we discuss two cases that aimed at a participatory approach: San Agustín and Agua Fría.

In San Agustín, there was participatory formulation. Formal community leaders defined the selection criteria, the model and materials of the houses, and selected the partner institutions and the social infrastructure to be built. In a first stage, meetings were held and representatives from each local association brought their designs and discussed them in assembly. In the second stage, the consultant met municipal committee leaders, local and government authorities, the priest, representatives of the vice-ministry of housing and other public institutions. To select the construction materials, leaders visited ten houses built with different construction materials (LD, 2001b). Finally, they chose the use of reinforced concrete, which they regarded as safer. All this was possible because the municipal committee had elaborated a development action plan (MSA, 2001) before the earthquakes struck, so that leaders were prepared to lead the efforts and propose alternatives.

In contrast, in Agua Fría, an intended participatory diagnosis was distorted by the local perception of likely project deliverables (cf., Mosse, 2004; 2005). The project was designed by outsiders; local leaders only remember to have been consulted. Participants could not introduce certain aspects that they valued, such as being able to work with credit or having access to good education and health care services. However, the small fish farming project (section 3.2) illustrates that leaders gained a certain influence on project decisions over time, especially when the role of the water company weakened.

Moreover, the Agua Fría project was complex; it became a 'pseudo-comprehensive' project (Hirschman, 1967/1995). Table 7 compares the activities of the two water projects.

\footnotetext{
${ }^{9}$ See Cooke and Kothari (eds., 2004) and Hickey and Mohan (eds., 2004) for cases that illustrate positive and negative sides of 'participation'.
} 
Table 7: Comparison of project activities: San Fernando (SF) and Agua Fría (AF)

\begin{tabular}{|lcccccccc|}
\hline & $\begin{array}{c}\text { Water } \\
\text { service }\end{array}$ & $\begin{array}{c}\text { Sanitation } \\
\text { systems }\end{array}$ & Latrines & Reforestation & $\begin{array}{c}\text { Soil protec- Solid wastes } \\
\text { tion }\end{array}$ & $\begin{array}{c}\text { Reservoir } \\
\text { mgmt. }\end{array}$ & $\begin{array}{c}\text { Eco-wood } \\
\text { stoves }\end{array}$ \\
\hline SF & Yes & Yes & Yes (-) & Yes & No & Yes & No & No \\
AF & Yes (-) & Yes (-) & Yes & Yes (+) & Yes & No & Yes & Yes \\
\hline
\end{tabular}

Legend: (-) means that the project had a worse performance or lower coverage, $(+)$ means that the activities were much greater in quantity and coverage

The Agua Fría design was well intended but included very many elements. Project staff lost track of technical aspects affecting the project's operational effectiveness, in a climate of reorganisation of the formal counterpart, and did not engage local stakeholders who could have supported the project outcomes (section 3.2). The residents face continuous problems with the water system and cannot solve them, as a man expresses: 'There have been like seven [water] leakages from Piedra Gorda to Trinchera. The last time, they had to break the paving stones of the road in order to fix the pipeline.'

\subsection{Conditionality practices}

'They did their work grumbling and grumbling.' (A social promoter in San Fernando)

'The project was not gone because we stuck together.' (A group of leaders in San Fernando)

For non-leaders, the main condition to benefit from the projects was to work in project activities. In San Fernando, new leaders felt compelled to participate in order to keep the project. Instead of favouring ownership (section 3.3), this work could have only served to achieve project outputs, at a relatively low cost. Fortunately, the interpersonal context and the institutional support of the mayor favoured the continuity of the leaders' efforts after the project.

Across cases, working in project activities could be differently interpreted by participants and have different effects on their autonomy. They could interpret their work as:

1. A condition imposed by an external entity, that has to be fulfilled, independently of one's opinion (e.g., 'we had to do it'; 'our opinions were not taken into account'; 'they [leaders] decided for us');

2. The fulfilment of an agreement to achieve a valuable goal, but they are doing what they are supposed to do (e.g., 'it was our contribution'; 'I did everything that was asked for');

3. The fulfilment of an agreement that brings happiness and pride because they are making an effort to improve their own life (e.g., 'we did not leave the project to decay'; 'San Agustín for San Agustín');

4. The fulfilment of an agreement whose process (the work) they are enjoying because they are learning a new skill, engaging with people 'bigger than them', sharing experiences with neighbours or working together.

The extent to which individuals agree with any of the previous interpretations depends on how they internalise their commitments (Ryan \& Deci, 2006). In the first case, there is no internalisation; people perceive their tasks solely as obligations, because they did not share in the decision to do them or, if they did, the contexts were so controlling that they felt they were working for someone else, not for themselves. Some people in Santa María perceived that their manual work became a commodity to be provided uniformly, without attention to special cases, for which they did not get a 'fair' compensation. Furthermore, expressing their opinions did not help much, as a woman recounts: 'We chose among the three models... we were considerate and chose that one in the middle... but they [the engineer and bricklayers] made the worst, the one that they wanted.' 
In the second case, people know that an agreement (in which they participated, directly or through their leaders) was reached because the final outcome is valuable. However, the activities linked to this agreement became obligations. In the water projects, participants highly valued the water connection and latrines, but they also worked on everything requested (e.g., sanitation systems, woodstoves) in order to get water.

In the third case, people are fulfilling a commitment, but they 'have in sight' the outcome. They feel happiness and pride because there is something in reach that they can do to help themselves and their community. They are intrinsically motivated. This is the case for most people in San Agustín and some in Santa María. It is also the case for work squads in Agua Fría while constructing the reservoir; people were highly motivated, for raising fish in the reservoir was their initiative, not the project's.

In the fourth case, people also enjoy the process of working together. This was the case for many women in San Fernando and Agua Fría. They shared time in training sessions, organised themselves for activities (e.g., a garbage carnival in San Fernando) or told other people about their experience (e.g., field trips in Agua Fría). It was less common in the reconstruction projects, which had harder work conditions.

This discussion confirms that the internalisation of work commitments depends on the project contexts, in addition to personality factors. Contexts can make an initially internalised commitment feel like an external imposition. For instance, hard and long workdays had different effects in San Agustín and Santa María. In San Agustín, there was a charismatic and committed project chief and residents trusted the donor that had funded another project in the past. In contrast, the residents in Santa María did not feel support from the executing NGO (and the donor was very distant), while management problems caused uncertainty about crucial project features. For many, motivation was externalised and their perceived agency was harmed.

Local perceptions of the role of community organisations in defining crucial project features (or a project itself) also influence the internalisation of work commitments, depending on the cultural role of leaders and their representativeness. Some people prefer and are confident to delegate crucial decisions to leaders and respect their agreements. This seems the case in San Agustín and Agua Fría in contrast to San Fernando (no previous organisation) or Santa María (self-nominated leaders). However, the delegation of decision-making and respectful attitudes might cover-up long-lasting social inequalities (Cleaver, 2004). On the other hand, people could ignore how decisions are made, due to specific community dynamics. For instance, in San Agustín, some people considered that project staff had a larger weight in decision-making than leaders so that fulfilling their work commitments was a sign of gratefulness. This perception was related to the high visibility of the project chief and poor information sharing between leaders and non-leaders due to the insecure local context and the hierarchical nature of the relations between the municipal committee, development associations and nonleaders.

\subsection{Coordination practices}

Structural contexts at different levels are important for identifying coordination challenges. At the international level, the degree of aid dependence of a country determines its relations with donors. Nicaragua is heavily aid dependent. ${ }^{10}$ At the national level,

\footnotetext{
${ }^{10}$ In year 2005, according to OECD (2008), ODA represented $15.4 \%$ of GNI for Nicaragua and $1.2 \%$ of GNI for El Salvador. Furthermore, 71\% of public investments were financed by foreign loans or grants in Nicaragua (GON, 2006).
} 
ongoing decentralisation of public functions and reforms in the water sector affected the relations between municipality authorities and public water companies.

The four projects had different coordination practices, which were related to (i) their organisational structure, entities involved, reporting chains, and responsibilities; (ii) their goals, which differed in number, complexity, and coverage of population and territory; and (iii) the informal relations that actually sustained the projects. Coordination was more challenging in the reconstruction cases. These projects were complex, required high negotiation skills from project staff and also creativity and flexibility to deal with many actors and multiple uncertainties. However, project staff also had more room to manoeuvre and engage actors. In contrast, the pre-defined role of the public water companies as local counterpart, executing and supervisory entities, constrained the range of possible coordination practices in the water projects.

The San Agustín case was the only case where the community organisation acted as a partner of project staff, sharing in relevant decision-making. Figure 3 shows the central role that the working group had in the functioning of this project.

Figure 3: The organisational structure of the San Agustín project

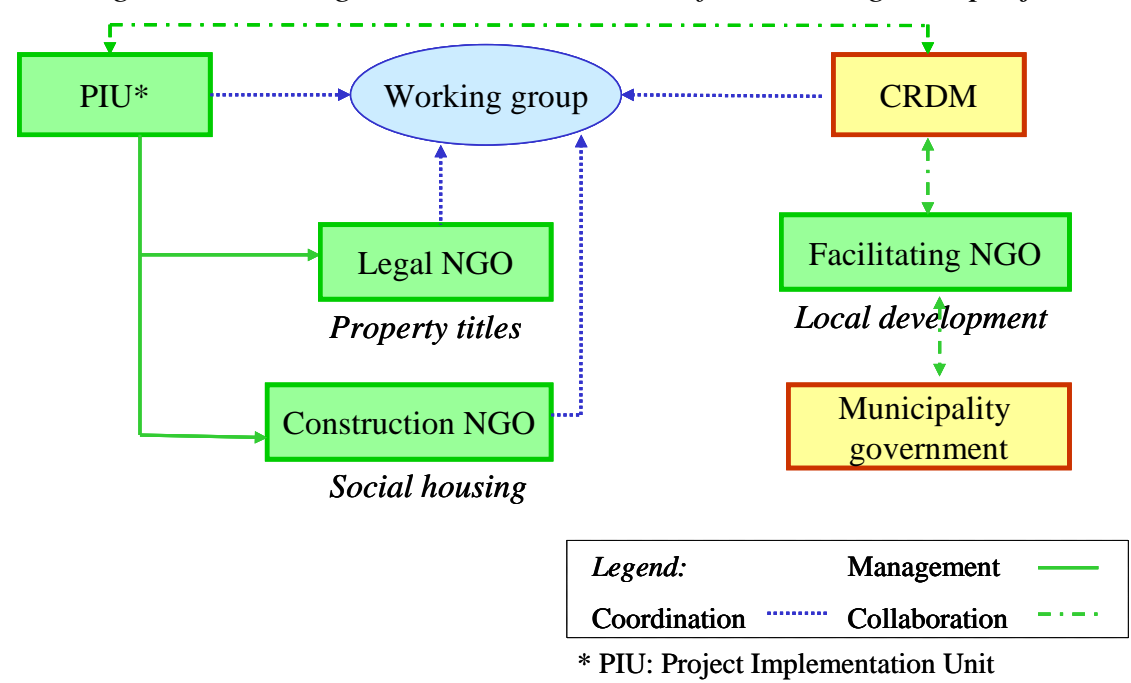

The working group was the main decision-maker. Within it, the project chief had the leading role, assisted by the president of the municipal committee. They coordinated the actions of the NGOs in charge of the registration of property titles and the construction of houses and social buildings. These NGOs also belonged to the working group, but with a secondary role. The facilitating NGO (the one supporting the elaboration of the municipal plan) participated at times in the weekly meetings of the working group. The project chief institutionalised a consensus building style, by which each entity had the chance to contribute or complain.

Many entities were directed or indirectly related to the project. The number of contacts increased because the project chief decided (i) to support the community organisation much more than the terms of reference had indicated, and (ii) to provide houses to as many people as possible despite the complexity of their legal situation, for instance by looking for land donors or alternative housing solutions (e.g., prefabricated houses). Coordination was difficult because of the initial lack of support of political authorities, public bureaucracies and private companies and the lack of administrative staff in the PIU. But as the project progressed, the departmental government and the Ministry of Foreign Affairs of El Salvador became facilitators of the project at the national level. 


\subsection{Accountability practices: processes and outcomes}

Accountability can be analysed with respect to (i) processes, where the focus is on activities, responsibilities, roles, and monitoring and evaluation, or (ii) outcomes, where the focus is on the relevance of the impacts.

Only in the San Agustín case was there mutual accountability with respect to processes between project staff and community leaders. The municipal committee was able to hold the mayor accountable given its increased access to information about the project and the municipality's financial situation.

In the other cases, with much lower involvement of leaders in the project (section 3.2), accountability was also lower. The Santa María case illustrates a situation worsened by organisational design problems: a subcontracted NGO coordinated three parallel projects from different donors, while being understaffed and without adequate monitoring by some of donors or the municipal government. The San Fernando case signals how accountability for outcomes can be reduced when there is no accountability for processes.

\section{- Poor accountability in Santa María harmed individual autonomy}

'Although the little house was like that, what could we do? We had to receive it anyhow because we needed it.' (A woman in Santa María)

The residents of Santa María saw themselves as partners of the executing NGO because they worked together. However, there was neither accountability with respect to processes, because residents were not even well-informed of decisions (made by external bodies), nor accountability with respect to outcomes when the outputs were not satisfactory. They are very grateful because they got a house, but their expectations were not fully met. They had no choice but to accept conditionality practices (section 4.2). Nonleaders could not find a receptive actor to whom to complain, while leaders tended to use the general dissatisfaction as a tool to pressurise project staff. Years after this housing project and other projects were completed, a woman reflects: 'Now we realise that, one, we have our house, and two, we have to do and consent to do what they [leaders] request us... because we [do not want] to have shortage'. Their poor living standards and lack of voice results in reduced autonomy.

Regarding the project outputs, one-half of the survey respondents in Santa María reported being very satisfied with the quality of their houses and no one reported being completely dissatisfied. The apparent suppression by some people of their complaints about housing may reflect the tense climate and damaged personal agency (including emotional distress) linked to the terrible disaster. In addition, the project did not finance the legalisation of the properties (section 2.2). To residents, this means that the project is unfinished. They feel insecure because they do not know how and when they will get their deeds. A woman explains: 'I sometimes think that I can be left... with the suitcase along the highway because... when one does not have the legal title, [it] is like not having anything'.

\section{- Accountability for outcomes at risk in San Fernando}

'When one has some pennies to eat, already one has to set them aside to pay the water. What is left? Stay hungry in order to pay; otherwise, they could cut off [the water service].' (A woman in San Fernando)

Most people in San Fernando felt satisfied over the regained access to potable water, but many had trouble to pay the water bills. Participants in all focus group discussions and 
$30 \%$ of the survey respondents complained about the bills and several households were having their water cut off ( $5 \%$ of the total, reported a woman leader). The situation highlights three problems: the application of a financial sustainability criterion to define water tariffs for a poor population, the initial mistrust of residents toward the project, and implementation gaps.

Given that most residents are income-poor, the project staff had identified the need for a tariff subsidy. It presented a proposal to the water company to subsidise $20 \%$ of the households, assuring the financial viability of the water system (i.e., the projected revenues covered the operation and maintenance costs). However, more people needed the subsidy, for the proposal underestimated the poverty rates. It stated that $5 \%$ of the households were extremely poor and 38\% were poor, while official poverty rates were $30 \%$ and $69 \%$ of the inhabitants, respectively (Muñiz Castillo, 2009). The project's estimates were based on a socio-economic census made at the start of the project and a household budget survey, but project staff suspected that people underreported their revenues in the census. So these revenues were adjusted with survey data on expenditure and census data on physical house condition (ibid, Box 8-1). Indeed residents had not collaborated with interviewers, who were strangers to them, did not trust the project would become a reality and did not know the purpose of the census (a woman leader).

Further, the water company had no presence in the promotion team. Belatedly organised workshops about water consumption and payments did not reach everyone or the message was not well explained (LD, 2005). People were confused: 'the month that I saved water, I paid the most' (a man). Besides, water meters were not tested on site when delivered. The high water bills added more discredit to the water company. A woman leader states: 'projects should not go to the hands of [the water company], but to the municipality government because the mayor would set a [fixed] tariff and we would agree to work all together'.

In sum, not all households had entitlement to safe drinking water given their low payment capacity. ${ }^{11}$ This harms individuals' autonomy. First, some people make sacrifices to pay the bills thus harming their health through not being well-fed. Second, some households use alternative non-safe water sources, such as river water, to control their expenses so that 'people have diseases again because the river is dirty' (a man). In addition, the nascent community organisation was weakened because the project was considered by participants as too little successful in securing water access for all residents.

\section{Exploring influences of project practices on individual autonomy}

The projects had varied effects on the determinants of autonomy: entitlements, agency and structural contexts. First, the most direct effect was on resources: provision of tangible project outputs such as houses, water services, home sanitation systems or wood stoves. However, people do not always use them in a way that supports their autonomy. For instance, those people who considered building the home sanitation systems as a duty (linked to conditionality practices) do not use and maintain them well, so that the effects on health are not as expected.

Moreover, resources provided by projects are not always accessible. Entitlements are based not only on legal ownership or rights, but also on social legitimisation. In San

\footnotetext{
${ }^{11}$ Everyone should have access to safe drinking water to promote their well-being, for equity reasons, but at the same time someone must pay. Our argument is that a decentralised water system managed by a community organisation or by a municipal government serving a poor community requires the support of a central water operator (or regulator) that transfers resources from surplus to deficit water systems.
} 
Fernando, some residents do not have their entitlement to safe drinking water secured, given their low payment capacity (section 4.4). In Santa María, communal land was available for the project, but residents had to use it in one specific way: planting together as a cooperative (section 3.1). Years later, they parcelled it out, although they hardly subsist with such small pieces of land and without credit.

Second, projects also supported personal agency as participants learned new skills, especially through their work as bricklayer assistants. Some men worked in reconstruction projects in nearby areas, were hired by project staff to construct the social buildings, or constructed small infrastructure in the water projects. However, the physical health and strength of some people in the reconstruction projects could have been harmed because they could not support themselves (section 3.3), thus delaying the works and also affecting interpersonal relations, in opposition to the intended positive effect of building relations.

In fact, projects that include self-construction activities could have several effects on perceived agency - how capable individuals feel that they are to undertake new endeavours or just to manage their lives under the circumstances in which they are (Muñiz Castillo, 2009). On the one hand, people could become aware of latent capacities or develop new ones. In Agua Fría, men gain this awareness from construction activities and women from sharing their experiences (e.g., how to use the ecological wood stoves) with residents from other villages. They could also strengthen their interpersonal relations. In San Fernando, a woman reflects: 'It is like the group gives strength, the union helps one to feel relieved'. They also felt more self-confident because they learned, enjoyed and worked together for the well-being of their families and community.

On the other hand, they could feel harmed by control-oriented project practices and lose their self-confidence. Power relations between participants and project staff are very important. If participants succeed to finish their commitments and reach the valued outputs, despite the adverse circumstances, they could feel proud. For instance, despite mistreatments, women in Santa María now feel more respected by men. A woman recounts:

'When the men arrived with the material [for the home sanitation system], they said, 'where are you going to make it?' I told them 'right here'. [They replied], 'Are you going to make it?' 'I am', I said, and I began to make it (laughs).'

Agency is the foundation of individual autonomy, but it is necessary to analyse whether the structural contexts support the exercise of autonomy. A person could feel capable but powerless to promote their own development. If this feeling persists and people see their efforts constantly frustrated, they could steadily lower their aspirations (cf., Cleaver, 2005). It seems that despite the long experience of leaders in Agua Fría, the poor reliability of the water system and the failure to register the NGO is causing disappointment in non-leaders because their efforts did not succeed. Only half of the survey respondents in Agua Fría said that the community would expand their opportunities.

Third, projects can influence the structural contexts in multiple ways, for instance, by supporting an ongoing positive change (in San Agustín), starting a community organisation from scratch (in San Fernando), unintentionally worsening local governance (in Agua Fría) or choosing non-representative local partners (in Santa María). An early engagement of project formulators in local communities could build the support of 'boundary partners' (Earl et al., 2002, cited by Crawford et al., 2005) such as communal leaders or local politicians. In that way, the chances for cooperation and mutual learning during the project would increase. 


\section{Conclusions}

We have explored elements of the project logic of four aid projects to consider their possible effects on individual autonomy. We suggest that the explicit inclusion of a human-autonomy effectiveness criterion in design, implementation, monitoring and evaluation of projects will help promote human development (Muñiz Castillo, 2009; Muñiz Castillo \& Gasper, 2009). In addition, it supports the achievement and sustainability of intended project goals, when these goals are valued by project participants.

We show that a crucial step to understand the (unintended) effects of project practices is to uncover the implicit assumptions that sustain these practices, either resulting from (externally defined) logical frameworks or from negotiated practices in particular contexts, which evolve during the project. Those assumptions concern values and needs, individual and group capacities, aspirations, local governance, and power structures. These assumptions are often wrong and put at risk the achievement of intended outcomes. If, nevertheless, they influence the behaviours of project staff and local stakeholders who aim to reach what is expected at all costs, pursuit of this constrained goal can harmfully affect the participants' autonomy.

Top-down project design or pseudo-participatory exercises will most likely pay no attention to crucial life aspects relevant to local participants and will make wrong assumptions. Community leaders might formally accept project goals and activities but work backstage to build relations with powerful outsiders and be able to make changes later. This strategy will be more or less effective depending on the formal power structures and community dynamics.

All four projects included self-construction activities, expected to favour local ownership of the projects. However, their actual practices could externalise the motivation of project participants when excessive conditionality made people feel like working for someone else, when their opinions were disrespected or when they were poorly informed about their entitlements. The effect on the participants' autonomy depends on their personal factors and the perceived role of the community organisations in such contexts.

The involvement of community organisations was different in each project case, but mostly served to support tangible project outputs (section 3.2). However, the San Agustín case illustrates how an aid project can go further and support an ongoing change process led by a community, engaging actors in structural contexts at different levels and working with a local social intermediary. The participatory formulation, the functioning of the working group and the elaboration of the municipal plan were possible thanks to the intrinsic motivation of local leaders and their developed organisational skills linked to their socio-historical experiences. In contrast, when project practices constrain the opportunities and perceived competence of individuals to help themselves, the 'development' or change promoted by those projects is not sustainable. 


\section{References}

Arnstein, S. R. (1969). A ladder of citizen participation. Journal of American Planning Association, 35 (4), 216-224.

Ausín Cantero, F.J. (2001a). Informe de misión: Proyecto NIC/009 Reconstrucción de Posoltega [Report of mission: Project NIC/009 Reconstruction Posoltega]. November 2001. Madrid: Desarrollo, Medio Ambiente y Salud (DMAS) Consultora S.A.

(2001b). Informe final de la misión para la realización del informe de clausura del proyecto NIC/009 Reconstrucción de Posoltega financiado por Lux-Development S.A. [Final report of the mission for the elaboration of the report of closure of the Project NIC/009 Reconstruction Posoltega, financed by LuxDevelopment S.A.] November 2001. Madrid: DMAS Consultora S.A.

Bennett, L., Goldberg, M., \& Hunte, P. (1996). Ownership and sustainability: Lessons on group-based financial services from South Asia. Journal of International Development, 8(2).

CENIDH [Nicaraguan Centre of Human Rights] (1998). Segundo informe sobre el huracán Mitch [Second report of CENIDH about hurricane Mitch]. Managua: CENIDH. Retrieved October 21, 2006, from http://www.gvom.ch/mitch/e11.html

Cernea, M. (1997). The risks and reconstruction model for resettling displaced populations. World Development, 25(10), 1569-1587.

Cleaver, F. (2004). The social embeddedness of agency and decision-making. In Hickey, S. \& Mohan, G. (Eds.), Participation: from tyranny to transformation? Exploring new approaches to participation in development (pp. 271-277). London and New York: Zed Books.

(2005). The inequality of social capital and the reproduction of chronic poverty. World Development, 33(6), 893-906.

CODECA (2003a). Informe final proyecto SVD/012 [Final report of project SVD/012]. From November 1, 2001 to October 31, 2003. La Unión: October 2003.

Cooke, B. \& Kothari, U. (Eds.) (2004). Participation: the new tyranny? London and New York: Zed Books (Original work published 2001).

Cooke, B. \& Kothari, U. (2004). The case for participation as tyranny. In Cooke, B. \& Kothari, U. (Eds.), Participation: the new tyranny? (pp. 1-15). London and New York: Zed Books.

Crawford, P. Swete Kelly, D., Mitchell, C. \& Bryce, P. (2005). Aristotle and Plato at it again? Philosophical divergence within international aid project design and monitoring \& evaluation [electronic paper]. Retrieved June 10, 2008, from http://www.aid-it.com.au/Portals/0/Documents/070105 _Aristotle\%20and\%20Plato\%20at\%20it\%20again.pdf

Deci, E.L. \& Ryan, R.M. (1985). The general causality orientations scale: self-determination in personality. Journal in Research on Personality, 19, 109-134.

(2000). The "what" and "why" of goal pursuits: human needs and the self-determination of behaviour. Psychological Inquiry, 11(4), 227-268.

Earl, S., Carden, F. \& Smutylo, T. (2002). Outcome Mapping: building learning and reflection into development programs. Ottawa: International Development Research Centre (IDRC).

Ellerman, D. (2006). Helping people help themselves: from the World Bank to an alternative philosophy of development assistance. Ann Arbor: The University of Michigan Press. Paperback edition.

Envío Team (1998). How Managua saw the passage of hurricane Mitch. Revista Envío, 209. Retrieved September 30, 2006, from http://www.envio.org.ni/articulo/1363

FLACSO (Latin American Faculty of Social Sciences) (2005). Mapa de pobreza: política social y focalización [Poverty map: social policy and targeting] (Vol. I). San Salvador: FISDL.

GON (Government of Nicaragua) (2001). Mapa de pobreza extrema de Nicaragua: Censo 1995 - EMNV 1998 [Nicaragua's extreme poverty map]. Retrieved January 19, 2006 from http://www.inec.gob.ni/ bibliovirtual/publicacion/mapapobreza2001.pdf

(2006) Informe liquidación del Presupuesto General de la República 2005 [Liquidation of the general budget report] General Budget Directorate, Ministry of Finances and Public Credit, Managua.

Herrera, A.E. (2003). Francisco Flores, un memorial de corrupción al frente de la presidencia de El Salvador [Fernando Flores, a brief of corruption in front of the presidency of El Salvador]. Boletín Incidencia y Compromiso. Pastoral Social Cáritas Panamá. Retrieved January 12, 2007, from http://www.caritaspanama.org/incidencia/realidad_lc/fransisco_flores_memorial_corrupcion.htm 
Hickey, S. \& Mohan, G. (Eds.) (2004). Participation: from tyranny to transformation? Exploring new approaches to participation in development. London and New York: Zed Books.

LD (Lux Development S.A.) (2001a). SVD/012 Agua y medio ambiente: San Alejo [Water and environment: San Alejo]. Formulation report. September 2001. Luxembourg: LD.

(2001b). El Salvador: misión de formulación (del 11 al 16 de septiembre) [El Salvador: formulation misión (from 11 to 16 September)]. Elaborated by M. Demare (consultant) and P. Rossignol.

(2001c). SVD/016 Reconstrucción San Agustín [Reconstruction San Agustín]. Formulation report. September 2001. Luxembourg: LD

(2004). Informe Final, SVD/012 Agua y Medio Ambiente: San Alejo [Final Report]. May 2004.

(2005). Informe de evaluación de medio término, NIC/012 Agua potable Nueva Segovia y Madriz [Intermediate evaluation report, Drinking water Nueva Segovia and Madriz], prepared by D. Kopitopoulos (preliminary version, April 22, 2005).

Mosse, D. (2004). Power relations and poverty reduction. In Alsop, R. (Ed.), Power, rights, and poverty: concepts and connections (pp. 51-67). Washington, DC and London: World Bank and DFID.

(2005). Cultivating development: an ethnography of aid policy and practice. London and Ann Arbor: Pluto Press

MSA (Municipality of San Agustín) (2001). Plan de acción para el desarrollo del municipio San Agustín. [Action plan for the development of the Municipality of San Agustín]. San Agustín. June 2001.

Muñiz Castillo, M.R. (2009). Human development and autonomy in project aid: Experiences from four bilateral projects in Nicaragua and El Salvador. Unpublished doctoral dissertation. Maastricht Graduate School of Governance, Maastricht University, The Netherlands.

Muñiz Castillo, M.R. \& Gasper, D. (2009). Looking for long-run development effectiveness: An autonomy-centred framework for project evaluation. MGSoG Working Paper, 2009/005. Maastricht: Maastricht University.

OECD (Organisation for Economic Co-operation and Development) (2008). Development Cooperation Report 2007, Vol. 9, No 1. Paris: OECD.

Osti, R. (2004). Forms of community participation and agencies' role for the implementation of waterinduced disaster management: protecting and enhancing the poor. Disaster Prevention and Management, 13(1), 6-12.

Ryan, R.M. \& Deci, E.L. (2006). Self-regulation and the problem of human autonomy: Does psychology need choice, self-determination, and will? Journal of Personality, 74(6), 1557-1585.

Thorp, R., Stewart, F. \& Heyer, A. (2005). When and how far is group formation a route out of chronic poverty? World Development, 33(6), 907-920.

Trolese, B. (1999). Bob Trolese's update on the hurricane relief efforts. March 18. Verbo Nicaragua. Retrieved June 13, 2006, from http://www.verbo.org/nicaragua/nica-old.htm

UNDP (United Nations Development Programme) (2005b). Una mirada al nuevo nosotros. El impacto de las migraciones [A glance at the new us: the impact of migrations]. Informe sobre Desarrollo Humano El Salvador (IDHES) 2005 [2005 Human Development Report]. San Salvador: UNDP. 
Photo 1: Panoramic view of San Fernando's urban centre (February, 2005)

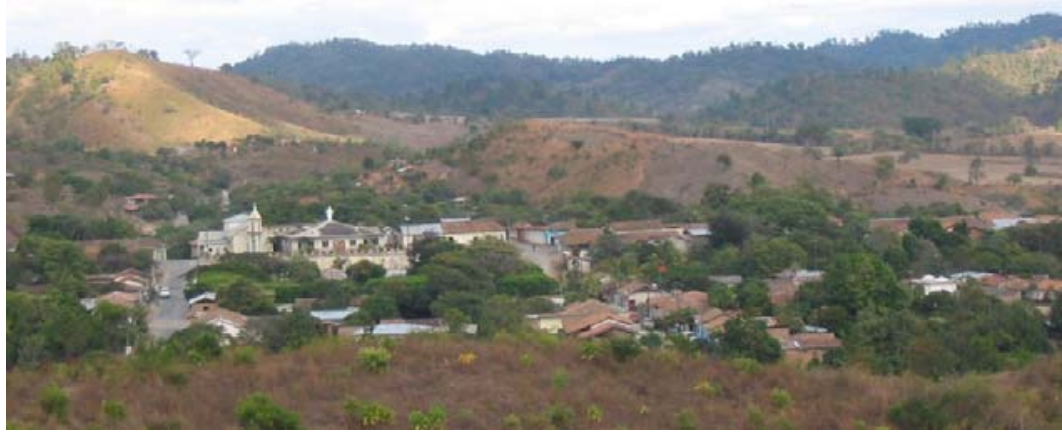

Photo 2: Assembly at a small village school, Agua Fría (August, 2005)

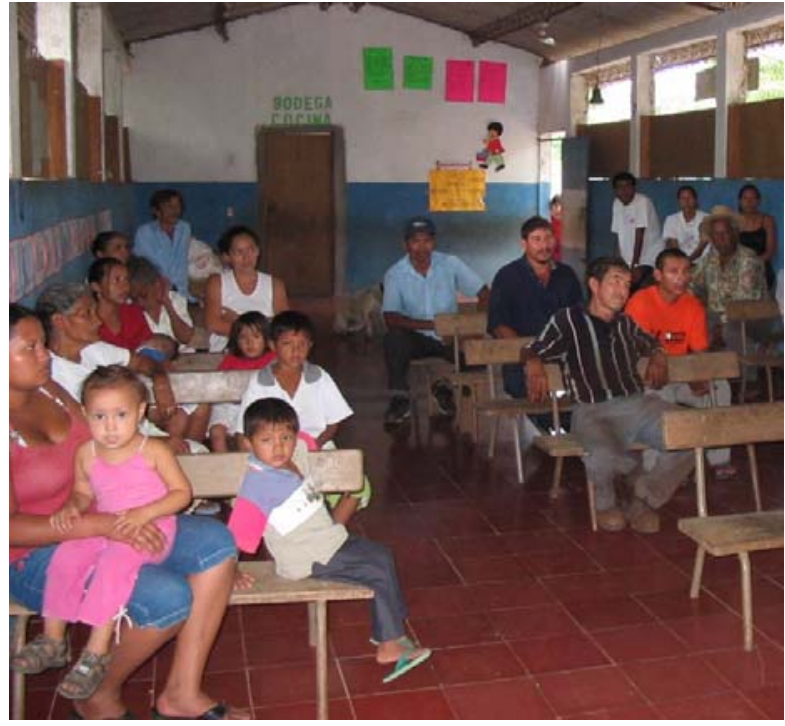

Photo 3: A new human settlement in San Agustín (September, 2005)

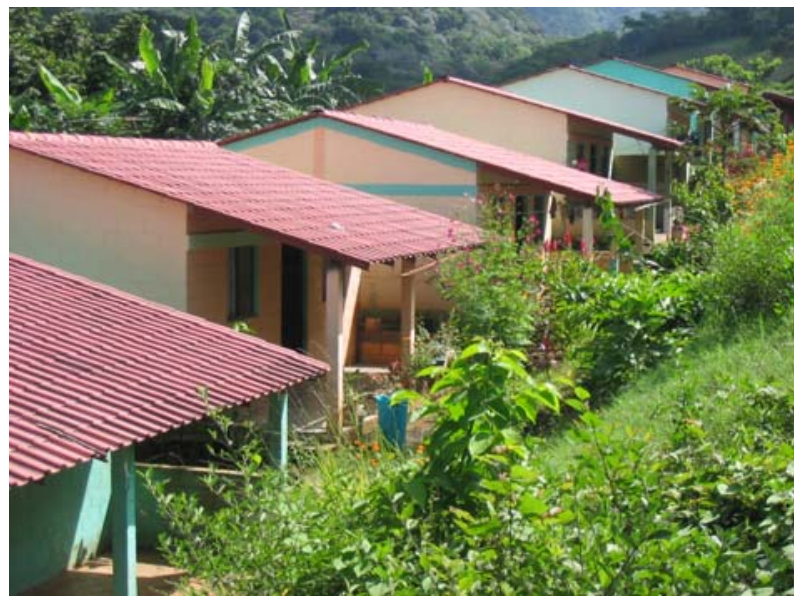




\section{Maastricht Graduate School of Governance}

Working Paper Series

\section{List of publications}

2009

\begin{tabular}{|c|c|c|}
\hline No. & Author(s) & Title \\
\hline$\overline{001}$ & $\begin{array}{l}\text { Roelen, K., } \\
\text { Gassmann, F. } \\
\text { and C. de } \\
\text { Neubourg }\end{array}$ & $\begin{array}{l}\text { Child Poverty in Vietnam - providing insights using a country-specific } \\
\text { and multidimensional model }\end{array}$ \\
\hline$\overline{002}$ & $\begin{array}{l}\text { Siegel, M. and } \\
\text { M. Lücke }\end{array}$ & $\begin{array}{l}\text { What Determines the Choice of Transfer Channel for Migrant Remit- } \\
\text { tances? The Case of Moldova }\end{array}$ \\
\hline$\overline{003}$ & $\begin{array}{l}\text { Sologon, D. and } \\
\text { C. O’Donoghue }\end{array}$ & Earnings Dynamics and Inequality in EU 1994 - 2001 \\
\hline$\overline{004}$ & $\begin{array}{l}\text { Sologon, D. and } \\
\text { C. O’Donoghue }\end{array}$ & Policy, Institutional Factors and Earnings Mobility \\
\hline$\overline{005}$ & $\begin{array}{l}\text { Muñiz Castillo, } \\
\text { M.R. and D. } \\
\text { Gasper }\end{array}$ & $\begin{array}{l}\text { Looking for long-run development effectiveness: An autonomy-centred } \\
\text { framework for project evaluation }\end{array}$ \\
\hline$\overline{006}$ & $\begin{array}{l}\text { Muñiz Castillo, } \\
\text { M.R. and D. } \\
\text { Gasper }\end{array}$ & $\begin{array}{l}\text { Exploring human autonomy effectiveness: Project logic and its effects } \\
\text { on individual autonomy }\end{array}$ \\
\hline
\end{tabular}

2008

\begin{tabular}{lll}
\hline No. & Author(s) & Title \\
\hline 001 & $\begin{array}{l}\text { Roelen, K. and F. Measuring Child Poverty and Well-Being: a literature review } \\
\text { Gassmann }\end{array}$ & \\
\hline 002 & Hagen-Zanker, J. & Why do people migrate? A review of the theoretical literature \\
\hline 003 & $\begin{array}{l}\text { Arndt, C. and C. } \\
\text { Omar }\end{array}$ & The Politics of Governance Ratings \\
\hline 004 & $\begin{array}{l}\text { Roelen, K., } \\
\text { Gassmann, F. } \\
\text { and C. de } \\
\text { Neubourg }\end{array}$ & $\begin{array}{l}\text { A global measurement approach versus a country-specific measure- } \\
\text { ment approach. Do they draw the same picture of child poverty? The } \\
\text { case of Vietnam }\end{array}$ \\
\hline 005 & $\begin{array}{l}\text { Hagen-Zanker, } \\
\text { J., M. Siegel and } \\
\text { C. de Neubourg }\end{array}$ & Strings Attached: The impediments to Migration \\
\hline 006 & $\begin{array}{l}\text { Bauchmüller, R. } \\
\text { Evaluating causal effects of Early Childhood Care and Education In- } \\
\text { vestments: A discussion of the researcher’s toolkit }\end{array}$ \\
\hline 007 & $\begin{array}{l}\text { Wu, T., Bor- } \\
\text { ghans, L. and A. } \\
\text { Dupuy }\end{array}$ & $\begin{array}{l}\text { Aggregate Shocks and How Parents Protect the Human Capital Accu- } \\
\text { mulation Process: An Empirical Study of Indonesia }\end{array}$ \\
\end{tabular}




\begin{tabular}{lll}
\hline 008 & $\begin{array}{l}\text { Hagen-Zanker, J. } \\
\text { and C. Azzarri }\end{array}$ & Are internal migrants in Albania leaving for the better? \\
\hline 009 & $\begin{array}{l}\text { Muñiz Castillo, } \\
\text { M.R. }\end{array}$ & $\begin{array}{l}\text { Una propuesta para analizar proyectos con ayuda internacional: De la } \\
\text { autonomía individual al desarrollo humano }\end{array}$ \\
\hline 010 & Wu, T. & Circular Migration and Social Protection in Indonesia \\
\hline
\end{tabular}

2007

\begin{tabular}{lll}
\hline No. & Author(s) & Title \\
\hline 001 & $\begin{array}{l}\text { Notten, G. and } \\
\text { C. de Neubourg }\end{array}$ & Relative or absolute poverty in the US and EU? The battle of the rates \\
\hline 002 & $\begin{array}{l}\text { Hodges, A. A. } \\
\text { Dufay, K. Dash- } \\
\text { dorj, K.Y. Jong, }\end{array}$ \\
& Money Programme \\
& T. Mungun and \\
U. Budragchaa
\end{tabular}

003 Hagen-Zanker, The determinants of remittances: A review of the literature J. and M. Siegel

\begin{tabular}{lll}
\hline 004 & Notten, G. & Managing risks: What Russian households do to smooth consumption \\
\hline 005 & $\begin{array}{l}\text { Notten, G. and } \\
\text { C. de Neubourg }\end{array}$ & $\begin{array}{l}\text { Poverty in Europe and the USA: Exchanging official measurement } \\
\text { methods }\end{array}$ \\
\hline 006 & $\begin{array}{l}\text { Notten, G and C. The policy relevance of absolute and relative poverty headcounts: } \\
\text { de Neubourg }\end{array}$ & What’s in a number? \\
\hline 007 & $\begin{array}{l}\text { Hagen-Zanker, } \\
\text { J. and M. Siegel }\end{array}$ & A critical discussion of the motivation to remit in Albania and Moldova \\
\hline 008 & Wu, Treena & $\begin{array}{l}\text { Types of Households most vulnerable to physical and economic threats: } \\
\text { Case studies in Aceh after the Tsunami }\end{array}$ \\
\hline 009 & Siegel, M. & Immigrant Integration and Remittance Channel Choice \\
\hline 010 & $\begin{array}{l}\text { Muñiz Castillo, } \\
\text { M.R. }\end{array}$ & Autonomy and aid projects: Why do we care?
\end{tabular}

\section{6}

\begin{tabular}{lll}
\hline No. & Author(s) & Title \\
\hline 001 & $\begin{array}{l}\text { Gassmann, F. } \\
\text { and G. Notten }\end{array}$ & $\begin{array}{l}\text { Size matters: Poverty reduction effects of means-tested and universal } \\
\text { child benefits in Russia }\end{array}$ \\
\hline 002 & $\begin{array}{l}\text { Hagen-Zanker, } \\
\text { J. and M.R. } \\
\text { Muñiz Castillo }\end{array}$ & Exploring multi-dimensional wellbeing and remittances in El Salvador \\
\hline 003 & Augsburg, B. & $\begin{array}{l}\text { Econometric evaluation of the SEWA Bank in India: Applying match- } \\
\text { ing techniques based on the propensity score }\end{array}$ \\
\hline 004 & $\begin{array}{l}\text { Notten, G. and } \\
\text { D. de Crom- } \\
\text { brugghe }\end{array}$ & Poverty and consumption smoothing in Russia \\
\hline
\end{tabular}




\section{No. Author(s) Title}

001 Gassmann, F. An Evaluation of the Welfare Impacts of Electricity Tariff Reforms And Alternative Compensating Mechanisms In Tajikistan

002 Gassmann, F. How to Improve Access to Social Protection for the Poor? Lessons from the Social Assistance Reform in Latvia 